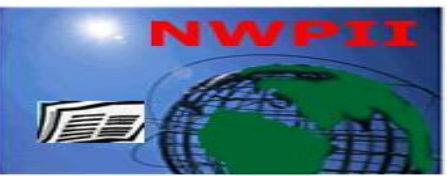

\title{
Development and Characterization of an Active Pharmaceutical Ingredient Using Polymeric Carriers Delivery System
}

\author{
Mohamed S. Abou-Taleb" ${ }^{*}$, Mohamed A. Khattab', Ahmed A. Ma'amoun' \\ ${ }^{1}$ Department of Materials Science, Institute of Graduate Studies and Research, Alexandria University, Egypt \\ "Corresponding Author \\ Mohamed S. Abou-Taleb \\ Department of Materials Science, Institute of Graduate Studies and Research, \\ Alexandria University, \\ Egypt. \\ Email: Mohamed.selim12@alexu.edu.eg, mselim_research@yahoo.com \\ Tel: +201222707520
}

Received:02 July 2021; | Revised:15 July 2021; | Accepted:04 December 2021

\begin{abstract}
Cardiac diseases are the major cause of mortality, morbidity, and disability. People are dying due to cardiac problems which include atherosclerosis and myocardial infarction. Nanotechnology is the science involving the design, characterization and application of materials in at least one dimension is on nanometer scale. Angiogenesis involves primary vascular plexus formation, which involves differentiation of endothelial cells. Gene therapy makes modification of gene expression for therapeutic gain, where a"normal" gene is inserted into the genome for replacement of an "abnormal" disease-causing gene. A carrier (a vector) is used for delivery of the therapeutic gene to the target cells of patient. Gene delivery involves the ability of DNA for crossing the cell membrane, escaping from endosome, and entering the nucleus. Vascular endothelial growth factor (VEGF) is a potent endothelial cell mitogen in vitro, and a potent permeability mediator and angiogenic growth factor in vivo. Poly (lactide-co-glycolide) (PLGA) is the most used polymer for pharmaceutical controlled release devices. PLGA is biodegradable and biocompatible, hydrolyzing to lactic and glycolic acid monomers. PLGA nanoparticles are potential vector for gene delivery.
\end{abstract}

Keywords: Cardiac diseases, Angiogenesis, Gene therapy, Vascular Endothelial Growth Factor, PolyLactide-co-Glycolide

\section{Introduction}

Cardiac diseases are the major cause of mortality and morbidity. People are dying of many cardiac problems including atherosclerosis and myocardial infarction. ${ }^{[1]}$ Oral and systemic administration of drugs, does not provide appropriate therapeutic drug levels in the target arteries. ${ }^{[2]}$

Cardiovascular diseases are the leading causes of death worldwide. Eighty million adults (one in three) in United States are estimated to have one or more types of cardiovascular disease. [3] CAD accounted for approximately 17.8 million deaths in 
2017. The number is expected to grow to more than 22.2 million by $2030 .{ }^{[4]}$

Thus, nanotechnology is an effective treatment modality for achievement of localized and sustained arterial and cardiac drug therapy to prevent cardiovascular diseases. ${ }^{[5]}$

Gene therapy is used for genetic disorders treatment or prevention by correction of defective genes responsible for development of disease by delivering of repaired genes or the replacement of incorrect ones. ${ }^{[6]}$

Nanoparticles formulation by PLGA polymer has greater gene transfection demonstration than formulation using PLA polymer in breast cancer this is due to higher DNA release from PLGA nanoparticles. ${ }^{[7]}$

Angiogenesis is a complex process in which its regulation is done by stimulatory and inhibitory factors and its initiation occurs when there is a predominance of angiogenic factors that favor the growth of new vessel, e.g. VEGF. ${ }^{8]}$

Non-viral gene transfer has been used for delivering genes to ischemic tissues for angiogenic therapy. Genes encoding proteins stimulating angiogenic signal transduction are administered by cationic polymers and lipids. ${ }^{[9]}$

Naked DNA, which is in the plasmid form, is the simplest form of non-viral transfer of the gene into a target cells. ${ }^{[10]}$

Non-viral gene carriers contain cationic region to condense the anionic therapeutic plasmid, thus protecting the plasmid from degradative nucleases. $^{[11]}$

Non-viral delivery of genes is safe than its viral delivery counterpart, involving complexing plasmids with cationic polymers or lipids that selfassemble with DNA forming particles able for cells endocytosis. ${ }^{[12]}$

Polymer-based gene vector are used in intravascular gene therapy utilizes the biocompatible and biodegradable PLGA, which have been approved for use in humans. ${ }^{[13]}$

The VEGF family has led to discovery of several members: VEGF-A of vascular permeability factor (firstly discovered), B, C, D, E, the family member concerned in angiogenesis is VEGF-A. ${ }^{[14]}$

PLGA is used polymer for pharmaceutical controlled release devices. ${ }^{[15]}$ The polyester, PLGA is biodegradable and biocompatible, hydrolyzing to monomers of lactic and glycolic acid. ${ }^{[16]}$ PLGA is a drug delivery carrier and FDA-approved as a biodegradable polymer, which has high biocompatiblity. ${ }^{[17]}$

The present work aimed to detect therapeutic effect of PcDNA3.1-VEGF which was constructed to be injected in rats, targeted to myocytes of infracted rat heart, also to indicate the therapeutic effect of gene transfer complex (Polyplex) formed by coupling of PcDNA3.1-VEGF and PLGA Nanoparticles to be injected in rats.

\section{Aim of the work}

To detect the therapeutic effect of PLGA Nanoparticles after gene transfection using PcDNA 3.1-VEGF targeted to myocytes. Also, to evaluate therapeutic effect of PcDNA3.1-VEGF - PLGA NPs (gene transfer complex, polyplex), the effect of therapeutic material PcDNA 3.1-VEGF and PLGA - NPs - BSA for myocardial infarcted animals treatment.

\section{Materials and Methods}

\subsection{Materials:}

We used 20 male rats: 4 healthy rats were used as negative control, and 16 animals had induced myocardial infarction with Isoprenaline Hydrochloride.

-Group I (Negative control): Non - injected 4 normal healthy animals.

-Group II (positive control): 4 normal healthy animals were induced myocardial infarction.

-Group III (Treatments): 12 animals, had induced myocardial infarction, and were divided into 3 treatments ( 4 animals each):

a-Treatment 1: Injected to induce myocardial infarction, then animals were injected with PcDNA 3.1-VEGF.

b-Treatment 2: Injected to induce MI, then animals were injected with PLGA-NPs-BSA.

c-Treatment 3: Injected to induce $\mathrm{MI}$, then animals were injected with PcDNA3.1-VEGFPLGA-NPs.

A blood sample from rats in each group was taken immediately from normal healthy, infarcted animals after one day, and after three, five, and 
seven days of infarction from treatments, then animals were sacrificed and hearts were taken.

\subsection{Methods:}

\subsubsection{The PcDNA3.1- VEGF construct:}

a-Many Plasmids used as expression vector can be propagated in Ecoli, PcDNA3.1, was purchased from Invitrogen carrying VEGF.

b-cDNA fragment of human VEGF obtained by reverse transcription-polymerase chain reaction (RT-PCR), using template mRNA, and a set of primers for VEGF

c-PcDNA3.1-VEGF concentration was $372.62 \mathrm{ug} / \mathrm{ml}$.

\subsubsection{Transformation Method for PcDNA3.1 carrying VEGF in E.coli: ${ }^{[18]}$}

\subsubsection{PcDNA3.1-VEGF description: ${ }^{[19]}$}

Lyophilized $5 \mu \mathrm{g}$ of the plasmid carrying VEGF was constructed.

\subsubsection{Transformation of E.Coli:}

a) $200 \mathrm{ml}$ competent cells were added to $10 \mathrm{ml}$ PGEM $\mathrm{T}$ recombinant for ligation and add $5 \mathrm{ul}$ construct (PcDNA3.1-VEGF) in an epindorf.

b)Keeping on ice for 40 minutes was made.

c)Heat shock at $420 \mathrm{C}$ for 45 seconds took place.

d)Keeping on ice for 5 minutes was done.

e) $200 \mathrm{ml}$ E.coli recombinant was added to 5 $\mathrm{ml} \mathrm{LB}$ broth in $50 \mathrm{ml}$ falcon tube.

f)Incubation at $37{ }^{\circ} \mathrm{C}$ for $2-4$ hours , $200 \mathrm{rpm}$ was made

g)Plating on LB/Amp/IPTG/x-gal agar plates took place.

h)Incubation at $37^{\circ} \mathrm{C}$ overnight was made.

i)Inoculating $1 \mathrm{ml}$ E.coli recombinant in $100 \mathrm{ml}$ LB broth and $100 \mathrm{ml} \mathrm{Amp} \mathrm{was} \mathrm{done.}$

j)Selection of colonies was made.

k)Purifying PcDNA3.1-VEGF from colonies was applied.

\subsubsection{Preparation and purification of PcDNA3.1 carrying VEGF ${ }^{[20]}$}

\subsubsection{Principle:}

1-Pelleted bacterial cells were resuspended and subjected to SDS/alkaline lysis to liberate the plasmid DNA.

2-Lysate was neutralized for binding of plasmid DNA on membrane in spin column.

3-Cell debris and SDS precipitate were pelleted by centrifugation, and the supernatant containing the plasmid DNA was loaded onto spin column membrane.

4-The adsorbed DNA was washed to remove contaminants, and was then eluted with a small volume of Elution Buffer.

5-The purified plasmid DNA was ready for use in PCR.

\subsubsection{Growth of Bacterial Cultures:}

1-Single colony was picked from a freshly streaked selective plate to inoculate $1-5 \mathrm{~mL}$ of LB medium supplemented with selection antibiotic and incubated for $12-16$ hours at $37^{\circ} \mathrm{C}$ while shaking at 2000-2500 rpm.

3-Bacterial culture harvested by centrifugation at $8000 \mathrm{rpm} 2 \mathrm{~min}$. Decantion of supernatant was done

4-5 mL of bacterial culture was taken.

\subsubsection{Plasmid DNA Purification Protocol:}

1-All purification steps were carried out at room temperature.

2-All centrifugations was carried out in microcentrifuge at $10000-14000 \mathrm{rpm}$.

3-1-5 mL of E. coli culture in LB media was used for purification.

Plasmid PcDNA3.1-VEGF purification was as follows:

1-The pelleted cells were resuspended in 250 $\mathrm{uL}$ of the Resuspension Solution. The cell suspension was transferred to a microcentrifuge tube. Vortexing until no cell clumps remained (RNase was added).

2-250 uL of the Lysis Solution was added and mixed thoroughly.

3-350 uL of the Neutralization Solution was added and mixed thoroughly.

4-Centrifugation for 5 min to pellet cell debris took place.

5-The supernatant was transferred to spin column by pipetting. 
6-Centrifugation for $1 \mathrm{~min}$ took place. The flow-through was discarded.

7-Spin column was washed by adding $500 \mathrm{uL}$ of Wash Solution I and centrifugated for 30-60 sec. Flow-through was discarded.

8-500 uL of the Wash Solution was added to spin column. Centrifugation for 30-60 seconds took place. Flow-through was discarded.

9-The washing was repeated using $500 \mathrm{uL}$ Wash Solution. Flow-through was discarded and centrifugation $1 \mathrm{~min}$.

10-Spin column was transferred into a fresh $1.5 \mathrm{~mL}$ microcentrifuge tube. $50 \mathrm{uL}$ of Elution Buffer was added and elution of the PcDNA3.1VEGF took place. Purified PcDNA3.1-VEGF was stored at $-20^{\circ} \mathrm{C}$.

\subsubsection{Preparation and Purification of RNA: ${ }^{[21]}$}

\subsubsection{Principle:}

Samples were lysed and homogenized in Lysis Buffer, containing guanidine thiocyanate, achaotropic protecting RNA from endogeneous RNases. Lysate was mixed with ethanol and loaded on purification column. Chaotropic salt and ethanol caused RNA to bind to silica membrane. Pure RNA was eluted under low ionic strength.

\subsubsection{Protocol:}

1-Blood cells were collected by centrifugation of $0.5 \mathrm{~mL}$ of whole blood at $400 \times \mathrm{g}$ for $5 \mathrm{~min}$ at $40 \mathrm{C}$. Blood cells would generate pellet.

2-Resuspension pellet in $600 \mu \mathrm{L}$ of Lysis Buffer supplemented with $\beta$-mercaptoethanol and vortexing was made.

3-Adding $450 \mu \mathrm{L}$ Ethanol (96-100\%) and mixing took place.

4-Transferring up to $700 \mu \mathrm{L}$ of lysate to Purification Column, centrifugation the column for 1 min at $\geqslant 12000 \times \mathrm{g}$ and discarding the flow through was made.

5-Repeating this step and discarding collection tube was made.

6-700 $\mu \mathrm{L}$ Wash Buffer 1 was added to Purification Column and centrifugation $1 \mathrm{~min}$ at $\geqslant$ $12000 \times$ g took place. Flow through was discarded.
7-600 $\mu$ L Wash Buffer 2 was added and centrifugation $1 \mathrm{~min}$ at $\geqslant 12000 \times \mathrm{g}$ took place. Flow through was discarded

8-250 $\mu$ L Wash Buffer 2 was added and centrifuged $2 \mathrm{~min}$ at $\geqslant 12000 \times \mathrm{g}$.

9-Discarding the collection tube containing flow-through.

10-10-50 $\mu \mathrm{L}$ Water nuclease-free was added. Centrifugation for $1 \mathrm{~min}$ at $\geqslant 12000 \times \mathrm{g}$ to elute RNA was made.

11- Purified RNA stored at $-20^{\circ} \mathrm{C}$.

\subsubsection{Treatment of RNA with DNase I: ${ }^{[22]}$}

\subsubsection{Description:}

1-DNase I was an endonuclease that digested single- and double-stranded DNA.

2-Enzyme activity was dependent on $\mathrm{Ca} 2+$ and is activated by $\mathrm{Mg} 2+$ ions, where DNase I cleaved each strand of dsDNA.

\subsubsection{Removal of genomic DNA from RNA preparations protocol:}

1.The following was added to tube:

\begin{tabular}{|c|l|}
\hline RNA & $1 \mu \mathrm{L}$ \\
\hline $\begin{array}{c}10 \mathrm{X} \text { reaction buffer } \\
\text { with MgCl2 }\end{array}$ & $1 \mu \mathrm{L}$ \\
\hline DNase I, RNase-free & $1 \mu \mathrm{L}(1 \mathrm{U})$ \\
\hline DEPC-treated Water & to $10 \mu \mathrm{L}$ \\
\hline
\end{tabular}

2. Incubation at $37^{\circ} \mathrm{C}$ for 30 min was made.

$3.1 \mu \mathrm{L} 50 \mathrm{mM}$ EDTA was added and incubated at $65^{\circ} \mathrm{C}$ for $10 \mathrm{~min}$.

4.Prepared RNA was used for reverse transcriptase.

\subsubsection{Synthesis of cDNA from total RNA: ${ }^{[23]}$}

\subsubsection{Protocol of cDNA synthesis:}

\subsection{Preparation of $2 X$ RT master mix:}

1) Kit components were thawn in ice.

2)Volume of components was as follows:

3)2 X RT master mix was placed on ice and mixed. 
Table 1: cDNA Reverse Transcription Kit Components

\begin{tabular}{|c|c|}
\hline component & $\begin{array}{c}\text { Volume reaction (ul) } \\
\text { With RNase Inhibitor }\end{array}$ \\
\hline 10X RT Buffer & 2.0 \\
\hline 25X dNTP Mix(100mM) & 0.8 \\
\hline 10X RT Random primers & 2.0 \\
\hline Reverse transcriptase & 1.0 \\
\hline RNase Inhibitor & 1.0 \\
\hline Nuclease-free $\mathrm{H}_{2} \mathrm{O}$ & 3.2 \\
\hline Total per Reaction & 10.0 \\
\hline
\end{tabular}

\subsection{Preparation the cDNA Reverse Transcription Reactions:}

a) $10 \mathrm{ul}$ of $2 \mathrm{X} \mathrm{RT}$ master mix was pipette into tubes.

b)10 ul of RNA sample was pipette into each tube. The tubes were sealed.
c)Centrifugation was done.

d)The tubes were placed on ice then loaded on thermal cycler.

\subsection{Performing reverse transcription:}

1)The thermal cycler was programmed:

Table 2:Conditions and Steps for Thermal Cycler

\begin{tabular}{|c|c|c|c|c|}
\hline Condition & Step 1 & Step 2 & Step 3 & Step 4 \\
\hline Temperature $\left({ }^{0} \mathrm{C}\right)$ & 25 & 37 & 85 & 4 \\
\hline Time & $10 \mathrm{~min}$ & $120 \mathrm{~min}$ & $5 \mathrm{~min}$ & $\infty$ \\
\hline
\end{tabular}

2)The reaction volume was set to $20 \mathrm{uL}$.

3)The reactions were loaded into thermal cycler.

4)The reverse transcription run was started.

5)cDNA was stored at 2 to $6{ }^{\circ} \mathrm{C}$.

\subsubsection{Quantization of mRNA using SYBR Green} qPCR: ${ }^{[24]}$

Rotor Gene Q-QIAGEN was used.

-Protocol:

1-Gently vortexing and centrifugation were made.

Reaction master mix was prepared:

Table 3: Components of SYBR Green Kit

\begin{tabular}{|c|c|}
\hline Maxima SYBR Green qPCR Master Mix (2X) & $12.5 \mathrm{ul}$ \\
\hline Forward Primer & $0.3 \mathrm{uM}$ \\
\hline Reverse Primer & $0.3 \mathrm{uM}$ \\
\hline Template DNA & $>500 \mathrm{ng}$ \\
\hline Water nuclease free & To 25 ul \\
\hline Total volume & $25 \mathrm{ul}$ \\
\hline
\end{tabular}

3-Master mix was mixed thoroughly and dispersed into PCR tubes.

4-The template DNA was added to PCR tubes containing master mix.

5-Reaction was mixed and Centrifugated.

6-Thermal cycler was programmed: 
Table 4: Steps, Temperature, Time and Number of Cycles for qrt-PCR

\begin{tabular}{|c|c|c|c|}
\hline Step & Temperature ${ }^{0} \mathrm{C}$ & Time & Number of cycles \\
\hline Initial Denaturation & 95 & $10 \mathrm{~min}$ & 1 \\
\hline Denaturation & 94 & $30 \mathrm{sec}$ & \multirow{2}{*}{50} \\
\hline Annealing & 57 & $30 \mathrm{sec}$ & \\
\hline Extension & 72 & $30 \mathrm{sec}$ & \\
\hline
\end{tabular}

3.2.8Preparation of PLGA Nanoparticles: ${ }^{[25]}$

3.2.8.1Materials needed for PLGA nanoparticles preparation:

1-PLGA [Sigma- Aldrich].

2-Bovine serum albumin (BSA).

3-Dichloromethane (DCM).

4-Poly-vinyl alcohol (PVA) [Sigma-Aldrich].

5-Milli-Q water.

\subsubsection{Steps for Preparation of PLGA Nanoparticles:}

a)PLGA was dissolved in organic phase $(4 \mathrm{ml})$, sonicated with addition of IAP (Internal Aqueous Phase), to make primary emulsion.

b)For formation of secondary emulsion $16 \mathrm{ml}$ of EAP (External Aqueous Phase), was added drop wise into primary emulsion during sonication.
c)Secondary emulsion was kept in magnetic stirrer overnight to evaporate excess DCM.

d)PLGA Nanoparticles were separated through centrifugation at $15000 \mathrm{rpm}$ for 20 mins.

e)Separated particles were washed twice with MQ water then lyophilized and stored in $-20^{\circ} \mathrm{C}$.

f)All of the above steps were done for preparation of PLGA-NPs- BSA.

g)Same methodology was done for PcDNA3.1-VEGF, but $10 \mathrm{ml}$ of EAP was instead of $16 \mathrm{ml}$.

\subsubsection{Preparation of PLGA-NPS by $\mathrm{W} / \mathrm{O} / \mathrm{W}$ technique:}

The following table shows reagents used for preparation of nanoparticles and gene transfer complex.

Table 5: Various PLGA nanoparticles Preparations reagents

\begin{tabular}{|c|c|c|c|c|c|c|}
\hline \multirow{2}{*}{ Preparations } & \multicolumn{3}{|c|}{ IAP } & \multicolumn{2}{c|}{ EAP } \\
\cline { 2 - 6 } & $\begin{array}{c}\text { PcDNA3.1- } \\
\text { VEGF }\end{array}$ & PLGA & BSA & DCM & $\begin{array}{c}\text { MQ - } \\
\text { water }\end{array}$ & PVA \\
\hline $\begin{array}{c}\text { PLGA-NPs } \\
\text { alone }\end{array}$ & Non & $0.2 \mathrm{~g}$ & Non & $4 \mathrm{ml}$ & $16 \mathrm{ml}$ & $0.16 \mathrm{~g}$ \\
\hline $\begin{array}{c}\text { PLGA-NPs - } \\
\text { BSA }\end{array}$ & Non & $0.2 \mathrm{~g}$ & $800 \mathrm{ul}$ & $4 \mathrm{ml}$ & $16 \mathrm{ml}$ & $0.16 \mathrm{~g}$ \\
\hline $\begin{array}{c}\text { PcDNA3.1- } \\
\begin{array}{c}\text { VEGF- PLGA- } \\
\text { NPs }\end{array}\end{array}$ & $250 \mathrm{ul}$ & $0.125 \mathrm{~g}$ & Non & $2.5 \mathrm{ml}$ & $10 \mathrm{ml}$ & $0.19 \mathrm{~g}$ \\
\hline
\end{tabular}

\subsubsection{Characterization of PLGA nanoparticles:}

\subsection{Morphology: ${ }^{[26]}$}

This was done using Jsm 1400 -+ Jeol Japan TEM Transmission Electron Microscope.

\subsection{Particle size analysis: ${ }^{[26]}$}

Analyzing of samples was done using Zetasizer Nano ZS Size Analyzer (Malvern, UK).

\subsection{Zeta potential: ${ }^{[27]}$}

This was determined using Zetasizer Nano ZS size analyzer, (Malvern, UK).

3.2.9Measuring Cardiac Enzymes of injected and non-injected animals (Cardiac profile):

\subsubsection{Creatine Kinase $(\mathrm{CK}):^{[28]}$}

\subsection{Principle:}

CK catalyzed phosphorylation of ADP, in presence of creatine phosphate to form ATP and creatine. Catalytic concentration was determined 
from the rate of NADPH formation; measured at $340 \mathrm{~nm}$.

Creatine phosphate $+\mathrm{ADP} \stackrel{\mathrm{CK}}{\longrightarrow}$ Creatine + ATP

ATP + Glucose $\stackrel{\mathrm{H}}{\longrightarrow}$ ADP + Glucose-6phosphate

Glucose-6- phosphate $+\mathrm{NADP}^{+} \stackrel{\mathrm{G} 6 \mathrm{PDH}}{\longrightarrow}$

6-phosphogluconate

$+\mathrm{NADPH}+\mathrm{H}^{+}$

\subsection{Procedure:}

1-One milliliters working solution and 50ul serum were pipette into cuvette.

2-Mixing and incubation 3 minutes took place.

2-Absorbance (A) of sample was read.

3-Average absorbance differences were calculated.

4- $\Delta \mathrm{A} / \min \mathrm{X} 3333=\mathrm{U} / \mathrm{L} \mathrm{CK}$ was performed.

\subsubsection{Creatine Kinase MB (CK-MB): ${ }^{[29]}$}

\subsection{Principle:}

Specific antibody inhibited $\mathrm{M}$ subunits of CK$\mathrm{MM}$ and thus allowed determination of $\mathrm{B}$ subunit of CK-MB, catalytic concentration was determined from rate of NADPH formation, measured at 340 $\mathrm{nm}$. ATP

Creatine phosphate + ADP $\stackrel{\mathrm{CK}}{\longrightarrow}$ Creatine +

ATP + Glucose

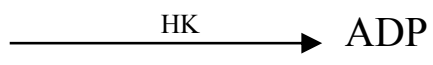

+ Glucose-6- phosphate

Glucose-6- phosphate + NADP ${ }^{+} \quad$ G6PDH

6-phosphogluconate +NADPH

$+\mathrm{H}^{+}$

\subsection{Procedure:}

1-One milliliter working solution and 50ul serum was pipette into cuvette.

2-Mixing and incubation for 3 minutes took place.

3-Initial absorbance (A) was read.

4-Average absorbance differences were calculated.

5- $\Delta \mathrm{A} / \mathrm{min} \mathrm{X} 6666=\mathrm{U} / \mathrm{L}$ CK-MB was performed.

\subsubsection{Lactate dehydrogenase (LDH): ${ }^{[30]}$}

LDH catalyzed reaction between pyruvate and NADH to produce $\mathrm{NAD}^{+}$and L-Lactate:

Pyruvate $+\mathrm{NADH}+\mathrm{H}^{+}$ LDH

L-Lactate $+\mathrm{NAD}^{+}$

The initial rate of $\mathrm{NADH}$ oxidation was directly proportional to catalytic LDH activity and was determined by measuring decrease in absorbance at $340 \mathrm{~nm}$.

\subsection{Procedure:}

1-one milliliter of working solution was added to $20 \mathrm{ul} \mathrm{specimen.}$

2-Mixing and measuring of absorbance after 30 seconds took place.

3-Mean absorbance was performed.

4- $\mathrm{LDH}$ activity was calculated using $\mathrm{U} / \mathrm{L}=$ $8095 \times \Delta \mathrm{A}$ at $340 \mathrm{~nm} / \mathrm{min}$.

\subsubsection{Investigation of the myocardium:}

1.The cardiac tissue was fixed at $10 \%$ ne formaldehyde.

2.Then dehydration in ascending grades of alcohol (70-100\%) was done.

3.Clearing in xylene took place.

4.Impregnation in molten paraffin at $60 \mathrm{OC}$ was made.

5.The blocks were cut into $5 \mu \mathrm{m}$ thick sections with microtome.

6.The paraffin sections were depraffinized with xylene then rehydrated in alcohol (70-100\%).

7.The slides were rinsed in haematoxylin stain, and then rinsed in eosin stain.

8.Then slides were dehydrated in the ascending series of alcohol and cleaned with xylene.

The slides were mounted by DPX, Covered and Photographed using Olympus light microscope

3.2.11Analyzing the QRT-PCR Data using Comparative CT Method ( $\Delta \Delta \mathrm{CT})$ :

Mean CT values were used in $\Delta \Delta$ CT calculations. Fold change expression of VEGF after treatment, was calculated:

\subsubsection{Calculations of the $\Delta \mathrm{CT}$ :}

$\Delta \mathrm{CT}=\mathrm{CT}$ target gene (VEGF) - CT reference gene (B-actin)

\subsection{Principle:}


3.2.11.2Calculations of the $\Delta \Delta \mathrm{CT}$ :

$\Delta \Delta \mathrm{CT}=\Delta \mathrm{CT}$ test sample $-\Delta \mathrm{CT}$ calibrator sample, by subtracting the $\Delta \mathrm{CT}$ of untreated from the $\triangle \mathrm{CT}$ of Treated. Calculation of fold expression was: $2-\Delta \Delta \mathrm{CT}$.

\subsubsection{Statistical analysis of the data:}

Using IBM SPSS software package version 20, ANOVA was performed.

\section{Results}

4.1Agarose gel electrophoresis for PcDNA3.1VEGF:

Isolated plasmid DNA was run on $1 \%$ agarose gel electrophoresis to check integrity of plasmid. Isolated plasmid was supercoiled in conformation. Plasmid had Ampicillin resistance gene to serve as selection marker. Concentration and purity of plasmid DNA were determined by Nanodrop device (Jenway). Three bands of PCDNA3.1VEGF appeared in the Agarose gel (marker 1K), highest band is for circular plasmid, middle is for linear plasmid lowest is for super coiled plasmid.

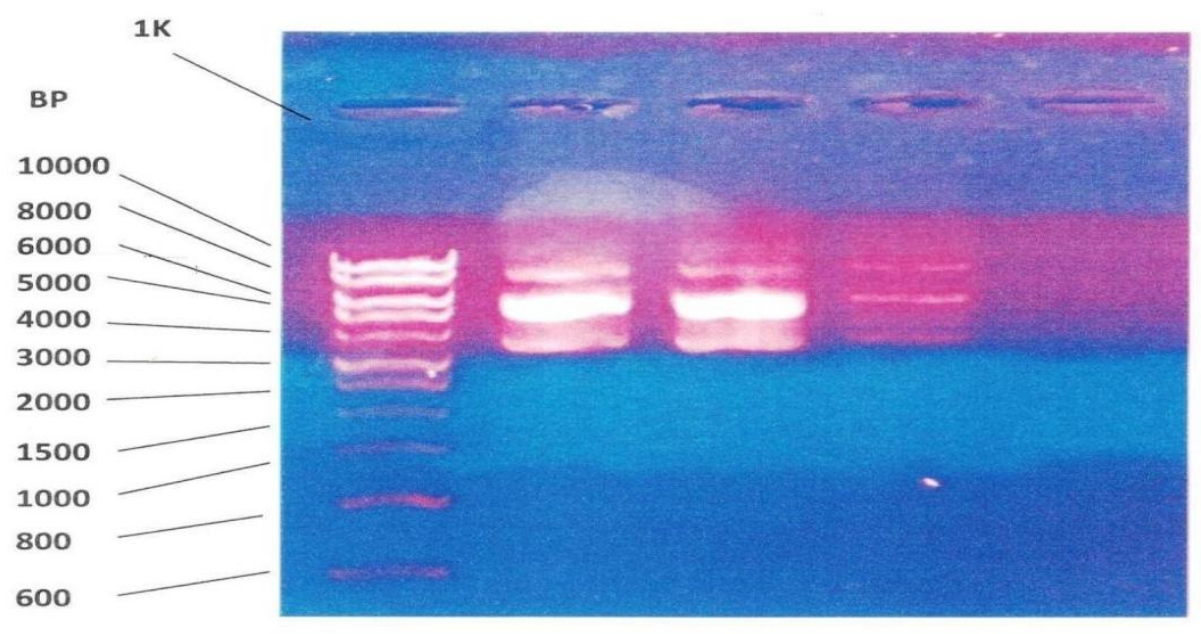

Figure 1: Agarose gel electrophoresis of PcDNA3.1-VEGF

Table 6: Concentration and purity of PcDNA3.1 -VEGF

\begin{tabular}{|c|c|c|}
\hline $\begin{array}{c}\text { Concentration of PcDNA3.1- } \\
\text { VEGF } \\
\text { ug/ml }\end{array}$ & Purity (260/280) & Purity (260/230) \\
\hline 372.62 & 1.776 & 0.916 \\
\hline
\end{tabular}


4.2 Characterization of PLGA-NPs:

(a)

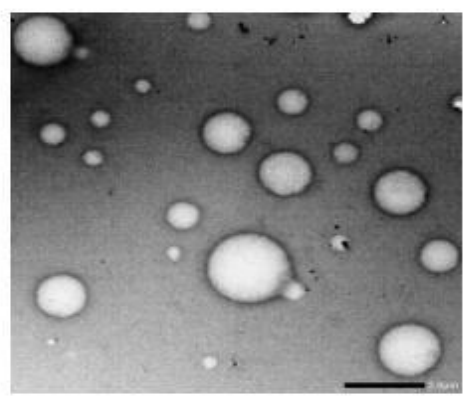

(c)

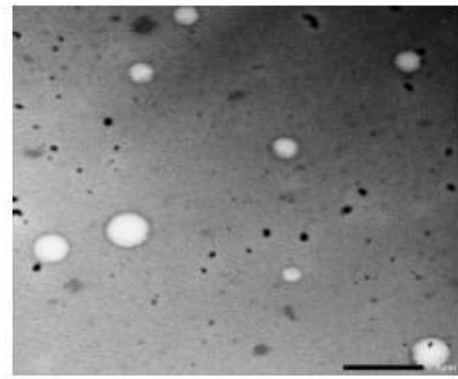

(b)

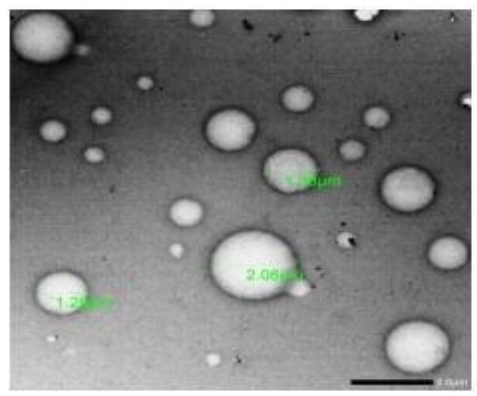

(d)

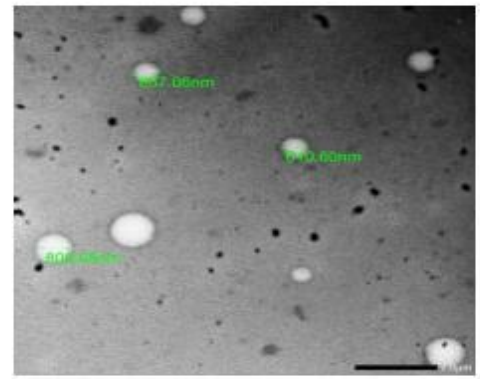

(e)

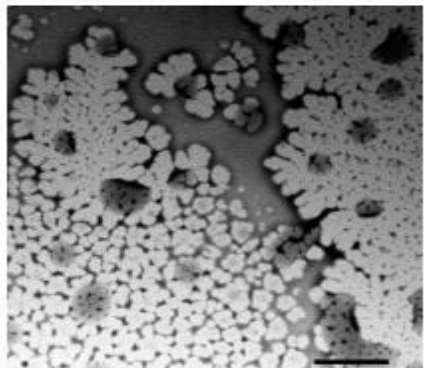

Figure 2: (a) TEM image for PLGA-NPs alone, (b) Particle size for PLGA-NPs alone, (Mean particle size is 1.58 um), (c) TEM image for PLGA-NPs - BSA, (d) Particle size of PLGA-NPs-BSA, (mean particle size is $691.4 \mathrm{~nm}$ ), (e) TEM image of gene transfer complex (polyplex)

\subsubsection{Zeta-sizer and Zeta potential:}

Zeta potential measures degree of repulsion between adjacent, charged particles in dispersion, a high zeta potential indicates stability.

Table 7: Size and \% intensity values of different samples

\begin{tabular}{|c|c|c|c|c|c|c|c|}
\hline Sample & Peaks & size & $\begin{array}{c}\% \\
\text { intensity }\end{array}$ & St. Dev. & Z-average & Intercept & PDI \\
\hline \multirow{3}{*}{$\begin{array}{l}\text { PLGA-NPs } \\
\text { alone }\end{array}$} & Peak 1 & 697.6 & 61.4 & 233.1 & \multirow{3}{*}{500.8} & \multirow{3}{*}{0.970} & \multirow{3}{*}{0.890} \\
\hline & Peak 2 & 131.0 & 25.4 & 39.39 & & & \\
\hline & Peak 3 & 24.63 & 7.4 & 4.296 & & & \\
\hline \multirow{3}{*}{$\begin{array}{c}\text { PLGA-NPs- } \\
\text { BSA }\end{array}$} & Peak 1 & 863.1 & 58.9 & 149.8 & \multirow{3}{*}{2494} & \multirow{3}{*}{0.969} & \multirow{3}{*}{1.000} \\
\hline & Peak 2 & 414.8 & 29.1 & 39.70 & & & \\
\hline & Peak 3 & 33.86 & 7.6 & 3.861 & & & \\
\hline \multirow{3}{*}{$\begin{array}{l}\text { PcDNA3.1- } \\
\text { VEGF-PLGA- } \\
\text { NPs }\end{array}$} & Peak 1 & 694.9 & 89.1 & 126.0 & \multirow{3}{*}{1422} & \multirow{3}{*}{0.877} & \multirow{3}{*}{0.946} \\
\hline & Peak 2 & 78.01 & 10.9 & 17.72 & & & \\
\hline & Peak 3 & 0.000 & 0.0 & 0.000 & & & \\
\hline
\end{tabular}


Table 8: Zeta potential and Zeta deviation values of different samples

\begin{tabular}{|c|c|c|c|c|c|c|c|}
\hline Sample & Peaks & Mean & $\begin{array}{c}\text { Area } \\
(\%)\end{array}$ & St. Dev. & $\begin{array}{c}\text { Zeta } \\
\text { Potential }\end{array}$ & $\begin{array}{c}\text { Zeta } \\
\text { Deviation(mv) }\end{array}$ & $\begin{array}{l}\text { Conductivity } \\
(\mathrm{mS} / \mathrm{cm})\end{array}$ \\
\hline \multirow{3}{*}{$\begin{array}{l}\text { PLGA-NPs } \\
\text { alone }\end{array}$} & Peak 1 & -3.25 & 53.1 & 3.96 & \multirow{3}{*}{-11.9} & \multirow{3}{*}{10.6} & \multirow{3}{*}{0.0354} \\
\hline & Peak 2 & -21.7 & 46.1 & 5.84 & & & \\
\hline & Peak 3 & 0.00 & 0.0 & 0.00 & & & \\
\hline \multirow{3}{*}{$\begin{array}{c}\text { PLGA-NPs- } \\
\text { BSA }\end{array}$} & Peak 1 & 2.85 & 100 & 4.42 & \multirow{3}{*}{2.85} & \multirow{3}{*}{4.42} & \multirow{3}{*}{0.0645} \\
\hline & Peak 2 & 0.00 & 0.0 & 0.00 & & & \\
\hline & Peak 3 & 0.00 & 0.0 & 0.00 & & & \\
\hline \multirow{3}{*}{$\begin{array}{c}\text { PcDNA3.1- } \\
\text { VEGF-PLGA- } \\
\text { NPs }\end{array}$} & Peak 1 & -14.3 & 100 & 6.86 & \multirow{3}{*}{-14.3} & \multirow{3}{*}{6.86} & \multirow{3}{*}{0.0243} \\
\hline & Peak 2 & 0.00 & 0.0 & 0.00 & & & \\
\hline & Peak 3 & 0.00 & 0.0 & 0.00 & & & \\
\hline
\end{tabular}

(a)

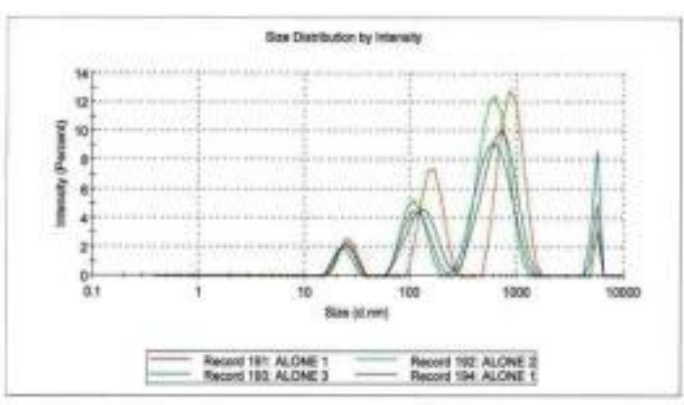

(c)

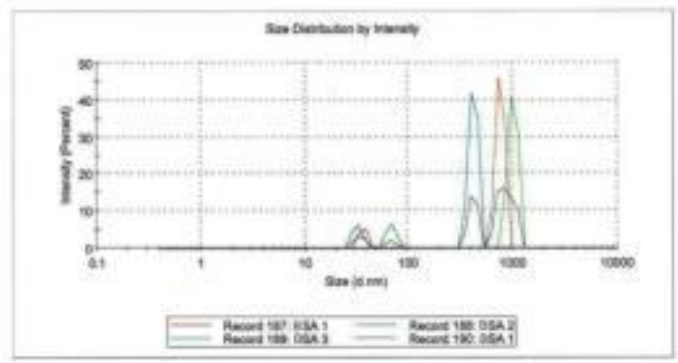

(e)

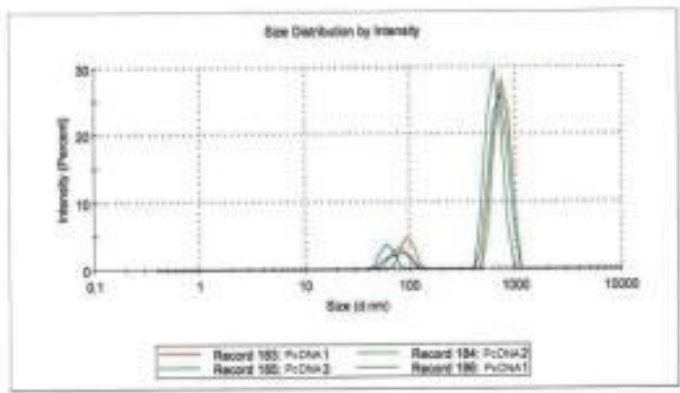

(b)

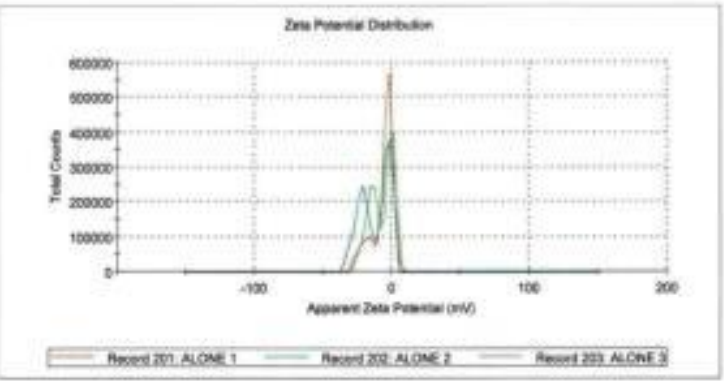

(d)

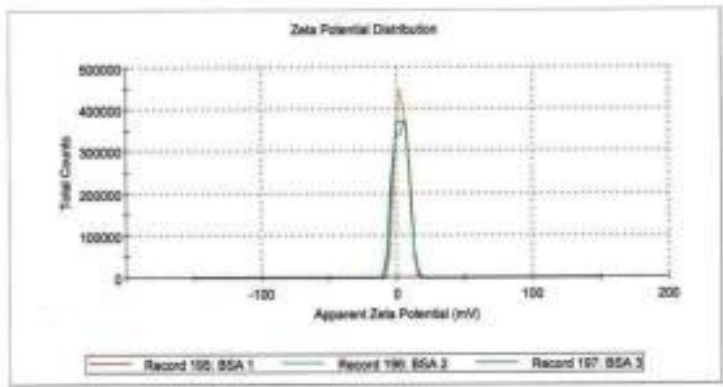

(f)

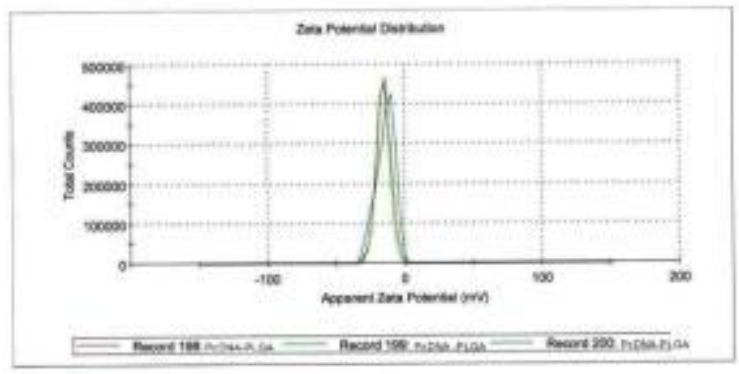

Figure 3: (a) Size Distribution for PLGA-NPs, (b) Zeta potential For PLGA-NPs alone sample, (c) Size Distribution for PLGA-NPs - BSA sample, (d) Zeta potential ForPLGA-NPs - BSA sample, (e) Size Distribution for PcDNA3.1-VEGF-PLGA-NPs (Polyplex), (f) Zeta potential for PcDNA3.1-VEGF-PLGA-NPs complex. 
(a)

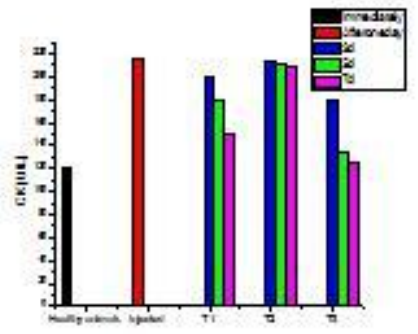

(d)

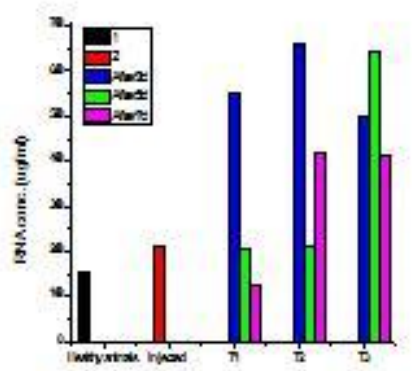

(b)

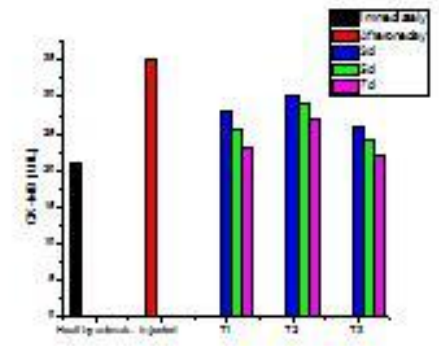

(e)

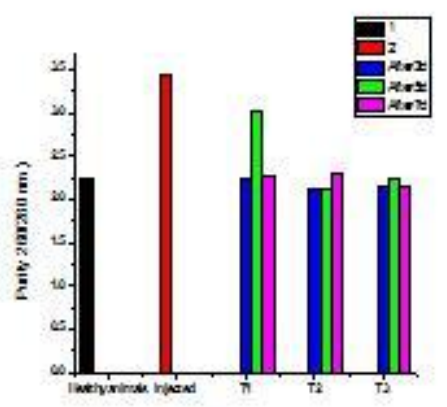

(c)

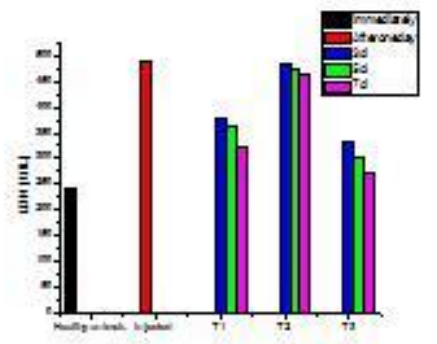

(f)

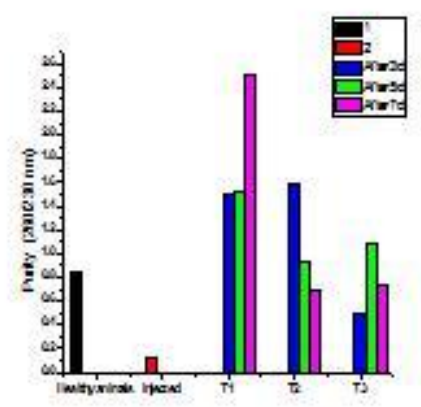

(g)

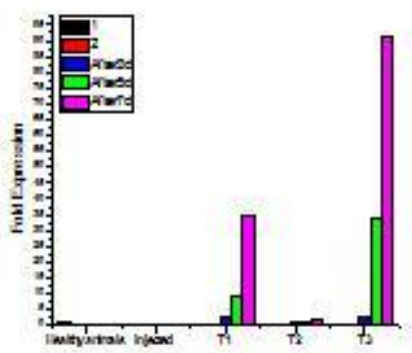

Figure 4: Graphical representation of, (a) CK (U/L) levels, (b) CK-MB (U/L) levels, (c) LDH (U/L) levels, and Comparison between studied groups regarding, (d) RNA concentration (ug/ml)

(e) RNA Purity 260/280 nm, (f) RNA Purity 260/230 nm, (g) fold expression. 


\subsection{Histopathological finding of heart tissue:}

(a)

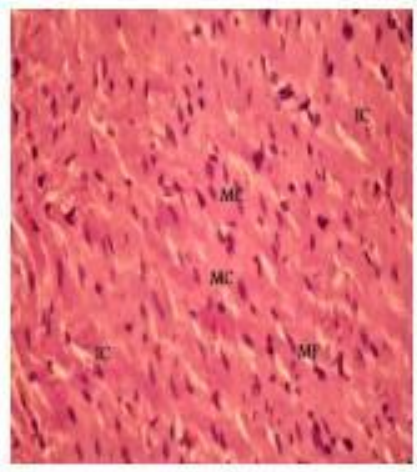

(c)

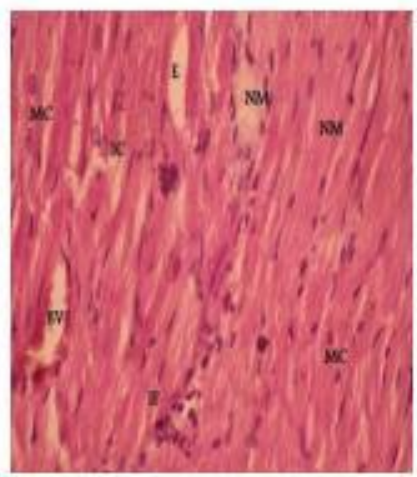

(b)

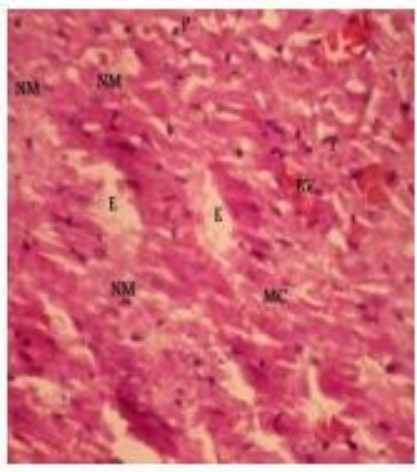

(d)

(e)

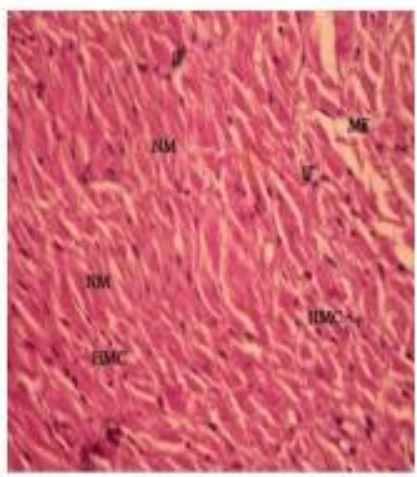

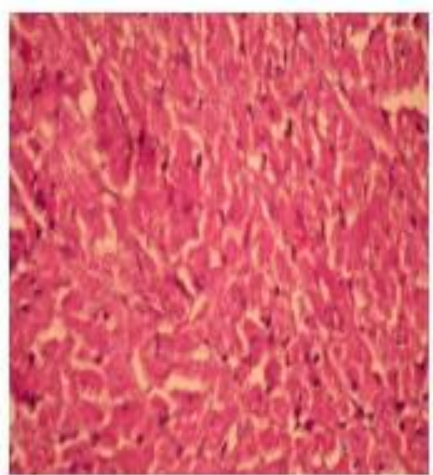

Figure 5: (a) Structure of myocytes of normal rat heart, (b) High power Paraffin section photomicrograph of myocardial infarcted rat group heart, (c) High power for T1 rat group heart showing some healthy myocytes, (d) High power for T2 rat group heart showing increased necrotic myocytes, (e) High power for T3 rat group heart showing higher healthy myocytes.

\section{Discussion}

Acute myocardial infarction takes place upon occlusion of one of the coronary Vessels, due to atherosclerotic plaque, resulting in an ischaemic region of myocardium. ${ }^{[31]}$

Nanotechnology is the understanding and control of matter at dimensions between 1 and 100 $\mathrm{nm}$, which helps in prevention and treatment of various diseases. ${ }^{[32]}$

Gene therapy is a useful technique using genes that prevent or recover diseases, this allow treating of disorders by inserting a gene in cell of patients instead of drugs. This takes place by replacement of mutant gene causing disease with healthy genes ${ }^{[33]}$

Gene transfering of angiogenic growth factors includes vascular endothelial growth factor
(VEGF), and hepatocyte growth factor (HGF), resulting in angiogenesis enhancement and functional recovering of ischemic tissues. ${ }^{[34]}$

Non-viral approaches began with delivering naked plasmid DNA, they are easier in manufacturing, purifying, chemically modifying, and can be scaled-up more than viral vectors. ${ }^{[35]}$

Cationic substances are polymers and lipids can be used as systems for non-viral gene transfer. Condensation of plasmid DNA carrying negative charge with positively charged cationic polymers or lipids can reduce plasmids size which enter cytoplasm and bind to cell membrane carrying negative charge and endocytosis occurs. ${ }^{[36]}$

Human VEGF family consists of 5 related glycoproteins VEGFA, VEGFB, VEGFC, VEGFD, and PIGF (Placental Growth Factor) which are 
interact with family of 3 receptors: VEGFR1, VEGFR2 and VEGFR3. ${ }^{[37]}$

PLGA is biodegradable, biocompatible and FDA approved for biomedical applications, so PLGA is used in drug delivery systems. ${ }^{[38]}$

Nanoparticle formulated using PLGA polymers are a new delivery system for genes due to their sustained release characteristics, and they are able for protecting DNA from endolysosomal degradation. ${ }^{[39]}$

PLGA polymer is biocompatible, biodegradable. Polymeric nanoparticles are used as pharmaceutical dosage form of proteins and peptides. Many methods are applied in preparing polymeric nanoparticles, as emulsificationevaporation method. ${ }^{[40]}$

Biodegradable PLGA show properties for biotechnology through their biocompatibility and their authorization by the Food and Drug Administration (FDA) for drug delivery. ${ }^{[41]}$

Encapsulating peptide or protein by PLGANPs takes place by water-oil-water $(\mathrm{w} / \mathrm{o} / \mathrm{w})$ emulsion technique. ${ }^{[42]}$

\section{Conclusions}

Non-viral gene delivery systems using plasmid DNA vectors are showing great promise in treatment of many diseases including Myocardial infarction.

Development of targeted PLGA nanoparticles carrier to a plasmid carrying genes such as VEGF has great benefit in gene expression in cardiac myocytes.

Gene targeting using biocompatible PLGANPs results in patient treatment of various diseases as myocardial infarction.

The gene transfer complex (Polyplex) "PcDNA3.1-VEGF-PLGA-NPs" in non-viral gene delivery showed highest expression level in mammalian myocytes, so it is mostly effective therapeutic material to obtain recovered myocardium and improving cardiac function.

\section{Acknowledgment}

I want to thank greatly Dr. Ahmed AbdelFattah Ma'amoun, Assistant Professor at Materials Science Department, Institute of Graduate Studies and Research, Alexandria University, for his great help and co-operation in this research.

\section{Conflict of Interest}

This research did not receive any specific grant from funding agencies in the public, commercial, or not for profit sectors.

\section{References}

1 Kong DF, Goldschmidt-Clermont PJ. Tiny solutions for giant cardiac problems. Trends Cardiovasc Med 2005; 15(6): 207-211 DOI: 10.1016/j.tcm.2005.07.003

2 Wickline SA, Neubauer AM, Winter P, Caruthers S, Lanza G. Applications of nanotechnology to atherosclerosis, thrombosis, and vascular biology.

ArteriosclerThrombVasc Biol 2006; 26(3): 435-441

DOI:

$\underline{\text { 10.1161/01.ATV.0000201069.47550.8b }}$

3 Lloyd-Jones D, Adams R, Carnethon M, De Simone G, Ferguson TB, Flegal K, Ford E, Furie K, Go A, Greenlund $\mathrm{K}$, Haase N, Hailpern S, Ho M, Howard V, Kissela B, Kittner S, Lackland D, Lisabeth L, Marelli A, McDermott M, Meigs J, Mozaffarian D, Nichol G, O'Donnell C, Roger V, Rosamond W, Sacco R, Sorlie P, Stafford R, Steinberger J, Thom T, Wasserthiel-Smoller S, Wong N, Wylie-Rosett J, Hong Y, American Heart Association Statistics C, Stroke Statistics S. Heart disease and stroke statistics--2009 update: a report from the American Heart Association Statistics Committee and Stroke Statistics Subcommittee. Circulation 2009; 119(3): e21-181 DOI: 10.1161/CIRCULATIONAHA.108.191261

4 Virani SS,Alonso A, Benjamin EJ, Bittencourt MS, Callaway CW, Carson AP, Chamberlain AM, Chang AR, Cheng S, Delling FN, Djousse L, Elkind MSV, Ferguson JF, Fornage M, Khan SS, Kissela BM, Knutson KL, Kwan TW, Lackland DT, Lewis TT, Lichtman JH, Longenecker CT, Loop MS, Lutsey PL, Martin SS, Matsushita K, Moran AE, Mussolino ME, Perak AM, Rosamond WD, Roth GA, Sampson UKA, Satou GM, 
Schroeder EB, Shah SH, Shay CM, SpartanoNL, Stokes A, Tirschwell DL, VanWagner LB, Tsao CW, American Heart Association Council on E, Prevention Statistics C, Stroke Statistics S. Heart Disease and Stroke Statistics-2020 Update: A Report From the American Heart Association. Circulation 2020; 141(9): e139-e596 [PMID: 31992061

DOI:

10.1161/CIR.0000000000000757]

5 Guccione S, Li KC, BednarskiMD. Vasculartargeted nanoparticles for molecular imaging and therapy. Methods Enzymol 2004; 386: 219-236 DOI: 10.1016/S0076$\underline{6879(04) 86010-5}$

6 Goverdhana S, Puntel M, Xiong W, Zirger JM, Barcia C, Curtin JF, Soffer EB, Mondkar S, King GD, Hu J, Sciascia SA, Candolfi M, Greengold DS, Lowenstein PR, Castro MG. Regulatable gene expression systems for gene therapy applications: progress and future challenges. Mol Ther 2005; 12(2): 189-211 DOI: $10.1016 /$ j.ymthe.2005.03.022

7 Prabha S,LabhasetwarV.Critical determinants in PLGA/PLA nanoparticle-mediated gene expression. Pharm Res 2004; 21(2): 354-364 DOI: $10.1023 / \mathrm{b}:$ pham.0000016250.56402.99

8 Drevs, J. VEGF and angiogenesis: imlications for breast cancer therapy, European Journal of Cancer, 2008, 6,7-13. [DOI:10.1016/S1359-6349(08)70287-8]

9 Yockman, J.; Kastenmeier, A.; Erickson, H.; Brumbach, J.; et al. Novel polymer carriers and gene constructs for treatment of myocardial ischemia and infarction, $\boldsymbol{J}$. Control Release, 2008, 132, 260-266. [DOI:10.1016/j.jconrel.2008.06.024]

10 Deelman L, Sharma K. Mechanisms of kidney fibrosis and the role of antifibrotic therapies. CurrOpin Nephrol Hypertens 2009; 18(1): $85-90$

DOI: 10.1097/MNH.0b013e32831c50a1

11 He CX, Tabata Y, Gao JQ. Non-viral gene delivery carrier and its three-dimensional transfection system. Int J Pharm 2010; 386(1-2): 232-242 DOI: 10.1016/j.ijpharm.2009.11.006

12 Bengali Z, Rea JC, Shea LD. Gene expression and internalization following vector adsorption to immobilized proteins: dependence on protein identity and density. $\boldsymbol{J}$ Gene Med 2007; 9(8): 668-678 DOI: 10.1002/jgm. 1058

13 Cohen-Sacks H, Najajreh Y, Tchaikovski V, Gao G, Elazer V, Dahan R, Gati I, Kanaan M, Waltenberger J, Golomb G. Novel PDGFbetaR antisense encapsulated in polymeric nanospheres for the treatment of restenosis. Gene Ther 2002; 9(23): 16071616 DOI: $10.1038 /$ sj.gt.3301830

14 Gospodarowicz D, Abraham JA, Schilling J. Isolation and characterization of a vascular endothelial cell mitogen produced by pituitary-derived folliculo stellate cells. Proc Natl Acad Sci USA 1989; 86(19): 7311-7315 DOI: $\underline{10.1073 / \text { pnas.86.19.7311 }}$

15 Tamber H, Johansen P, Merkle HP, Gander B. Formulation aspects of biodegradable polymeric microspheres for antigen delivery. Adv Drug Deliv Rev 2005; 57(3): 357-376 DOI: $\underline{10.1016 / j . a d d r .2004 .09 .002}$

16 Shameem, M.; Lee,H.; Deluca, P. A short term quality control tool for biodegradable microspheres, AAPS PharmSci, 1999, 1, 7

17 Jain RA. The manufacturing techniques of various drug loaded biodegradable poly(lactide-co-glycolide) (PLGA) devices. Biomaterials 2000; 21(23): 2475-2490 DOI: 10.1016/s0142-9612(00)00115-0

18 Ausubel, F; et al. Further information is provided in Current Protocols in Molecular Biology, 1994.

[DOI:10.1002/0471142727.mb1900s96]

19 Andersson S, Davis DL, Dahlback H, Jornvall H, Russell DW. Cloning, structure, and expression of the mitochondrial cytochrome P-450 sterol 26-hydroxylase, a bile acid biosynthetic enzyme. J Biol Chem 1989; 264(14): 8222-8229 [PMID: 2722778]

20 Birnboim, H.; Doly, J. A rapid alkaline lysis procedure for screening recombinant Plasmid DNA, Nucleic Acids Res, 1979, 7, 1513 1522. [DOI:10.1093/NAR/7.6.1513]

21 Boom R, Sol CJ, Salimans MM, Jansen CL, Wertheim-van Dillen PM, van der Noordaa J. Rapid and simple method for purification of nucleic acids. J Clin Microbiol 1990; 28(3): 
495-503

DOI: $\quad \underline{10.1128 / \mathrm{jcm} \cdot 28.3 .495-}$

$\underline{503.1990}$

22 Thermoscientific DNase I,RNase free. E No52, www. thermofisher.com

23 Thermo Scientific High capacity cDNA Reverse Transcription Kit. www.thermoscientific.com/manual. pp 6-9

24 Longo MC, Berninger MS, Hartley JL. Use of uracil DNA glycosylase to control carry-over contamination in polymerase chain reactions. Gene 1990; 93(1): 125-128 [PMID: 2227421 DOI: $10.1016 / 0378-1119(90) 90145-\mathrm{h}]$

25 VandervoortJ, Ludwig A . Biocompatible stabilizers in the preparation of PLGA nanoparticles: a factorial design study. Int $\boldsymbol{J}$ Pharm 2002; 238(1-2): 77-92 DOI: 10.1016/s0378-5173(02)00058-3

26 Jawahar, N.; Eagappanath, T.; Nagasamy, V.; et al. Preparation and Characterization of PLGA - Nanoparticles containing an Antihypertensive agent, International Journal of Pharm Tech Research, 2009, 1(2),390-393

27 Mahboobeh, M.; Mohammed, E.; Fatemeh, A. Laser Thrombosis and In vitro study of tPA release Encapsulated by Chitosan Coated PLGA Nanoparticles for AMI, International Journal of Biology and Biomedical Engineering, 2010, 2(4),35-42.

28 Horder, M. IFCC methods for measurement of catalytic concentration of enzymes. IFCC Method for Creatine Kinase, JIFCC, 1989, $1,130-$

139. DOI: $10.1155 / \mathrm{S} 1463924690000049$

29 Urdal P, Landaas S. Macro creatine kinase BB in serum, and some data on its prevalence. Clin Chem 1979; 25(3): 461-465 [PMID: 262189]

30 Young DS. Effects of drugs on clinical laboratory tests. Ann Clin Biochem 1997; 34 ( Pt 6): 579-581 [PMID: 9366995 DOI: 10.1177/000456329703400601]

31 Burchfield, J.; Xie, M.; Hill, J. Pathological ventricular remodeling: mechanisms: part 1 of 2, Circulation, 2013, 128,388-400. [DOI:10.1161/CIRCULATIONAHA.113.001 878]

32 Mahboob T, Nawaz M, de Lourdes Pereira M, Tian-Chye T, Samudi C, Sekaran SD, Wiart C, Nissapatorn V. PLGA nanoparticles loaded with Gallic acid- a constituent of Leea indica against Acanthamoeba triangularis. Sci Rep 2020; 10(1): 8954 DOI: 10.1038/s41598-020$\underline{65728-0}$

33 Sung YK, Kim SW. Recent advances in the development of gene delivery systems. Biomater Res 2019; 23: 8 DOI: 10.1186/s40824-019-0156-Z

34 Go AS, Mozaffarian D, Roger VL, Benjamin EJ, Berry JD, Borden WB, Bravata DM, Dai S, Ford ES, Fox CS, Franco S, Fullerton HJ, Gillespie C, Hailpern SM, Heit JA, Howard VJ, Huffman MD, Kissela BM, Kittner SJ, Lackland DT, Lichtman JH, Lisabeth LD, Magid D, Marcus GM, Marelli A, Matchar DB, McGuire DK, Mohler ER, Moy CS, Mussolino ME, Nichol G, Paynter NP, Schreiner PJ, Sorlie PD, Stein J, Turan TN, Virani SS, Wong ND, Woo D, Turner MB, American Heart Association Statistics C, Stroke Statistics S. Heart disease and stroke statistics--2013 update: a report from the American Heart Association.Circulation 2013; 127(1): e6-e245 DOI: 10.1161/CIR.0b013e31828124ad

35 Silva, G.; Litovsky, S.; Assad, J.; Sousa, A.; et al. Mesenchymal stem cells differentiate into an endothelial phenotype, enhance vascular density, and improve heart function in a canine chronic ischemia model, Circulation, 2005, $111,150 \quad-\quad 156$. [DOI:10.1161/01.CIR.0000151812.86142.45]

36 Green, J.; Langer, R.; Anderson, D. A combinatorial polymer library approach yields insight into nonviral gene delivery, $\boldsymbol{A c c}$. Chem. Res, 2008, 41,749 - 759. [DOI:10.1021/ar7002336]

37 Pandey AK, Singhi EK, Arroyo JP, Ikizler TA, Gould ER, Brown J, Beckman JA, Harrison DG, Moslehi J. Mechanisms of VEGF (Vascular Endothelial Growth Factor) Inhibitor-Associated Hypertension and Vascular Disease. Hypertension 2018; 71(2): e1-e8

DOI:

10.1161/HYPERTENSIONAHA.117.10271

38 Diego, P.; Macro, C.; et al. PEGylated PolyLactide (PLA) and Poly (Lactic-co-Glycolic acid) (PLGA) Copolymers for Design of Drug Delivery Systems, Journal of 
Pharmaceutical Investigations, 2019, 49,443-458. [DOI: $\underline{10.1007 / \mathrm{s} 40005-019-}$ 00442-2]

39 Panyam J, Zhou WZ, Prabha S, Sahoo SK, Labhasetwar V. Rapid endo-lysosomal escape of poly(DL-lactide-co-glycolide) nanoparticles: implications for drug and gene delivery. FASEB J 2002; 16(10): 1217-1226 DOI: $10.1096 /$ fj.02-0088com

40 Allemann, E.;Leroux, R. Biodegradable nanoparticles of particles of poly (lactic acid) and poly (lactic-co-glycolic acid) for parenteral administration. In: Gregoridas G, Ed. Pharmaceutical Dosage Form, New York, NY: Marcel Dekker, 1999, 163-186
41 Jain RA. The manufacturing techniques of various drug loaded biodegradable poly(lactide-co-glycolide) (PLGA) devices. Biomaterials 2000; 21(23): 2475-2490 DOI: $\underline{10.1016 / \mathrm{s} 0142-9612(00) 00115-0}$

42 Freitas S ,Merkle HP, Gander B. Microencapsulation by solvent extraction/evaporation: reviewing the state of the art of microsphere preparation process technology. J Control Release 2005; 102(2): 313-332 DOI: $\underline{\text { 10.1016/j.jconrel.2004.10.015 }}$ 